\title{
EMPLOYMENT PROBLEMS IN WEST GERMANY A Comment
}

\author{
FRANK P. STAFFORD \\ University of Michigan
}

\section{EROSION OF ADVANCED COUNTRY RENTS, INSURANCE, AND SYSTEM SOLVENCY}

As Soltwedel's paper documents, the labor-market functioning of the West German economy has been weak by a number of measures: unemployment has been rising, the rate of growth of employment has slowed and the prospects for near-term improvement seem dim. Unemployment for 1987 is averaging close to 8 percent, even though capacity utilization is higher than in any of the last 27 years except 1979. (See Graph 1 in this paper.) Why has this happened? Was not Germany the advanced industrialized country (AIC) with the exemplary record of growth and low unemployment which was used as a benchmark by critics of United States labor-market performance? What happened to the unemployment rates of less than 2 percent which prevailed during the 1960s? According to the paper, this sorry state of affairs is the consequence of a wide range of policy and institutional constraints on the market process which have given rise to wage rigidity and barriers to resource mobility.

Soltwedel argues that the policy and institutional restrictions have given rise to the labor market problems, and that existing theories of the relation between unemployment and wage rigidity, such as the efficiency wage hypothesis, the implicit contract model, and even his somewhat preferred alternative, the "insider-outsider" approach, are weak reeds in the wind when compared to a more straightforward interpretation of governmental and institutional failure. Since I agree with most of his main points, perhaps I was not a good choice as a discussant. Rather than ending here, I would like to provide a broader framework within which to interpret these fallures and to look at additional evidence on the costs of market restrictions, some of which supports his general view and some of which does not.

My main thesis is that much of what he documents as labor-market 
intervention can be interpreted as a variety of social insurance mechanisms which have at least partly failed. Moral hazard costs and issues of solvency are accentuated by erosion of the economic rents or quasi-rents of high technology countries like West Germany. This erosion of rents has been brought about by emerging international competition.

\section{A. An Insurance Framework of Intervention and Institutions}

During the glory days of economic expansion in Germany, there was relatively little risk for displaced workers. A lost job arising from a demand or technological change could be quickly replaced. Similarly, in Sweden national labor-market policy could be centered on the idea that no one's job was guaranteed but that, via labor-market mobility, everyone could be guaranteed a job in an expanding economy. This seemed to work, but then as economic growth continued so, too, did the international division of labor. No longer were there a few select "industrialized countries" which had a dominant share of manufactured wealth, and, just as assumed in trade models, the basic manufacturing technology did become available to a wide array of competitors (i.e., the NICs). While the advanced industrialized countries were better off for the usual arguments about the gains to trade, they probably also lost, because their status as sole suppliers of goods based on advanced technological processes was challenged. This simultaneous process of international specialization and erosion of "advanced country quasi-rents" is not one which has proceeded smoothly. Cost advantages based on cumulative output or the "industrial learning curve" of industries in the established countries were surmounted by new entrants, and swings in exchange rates led to abrupt reversals of the roles of leader and follower. These patterns are exemplified by the United States position in television, semiconductors, autos, and earthmoving equipment.

The recent experience of the advanced industrialized countries (AICs) is part of a more general consequence of specialization, which promotes economic growth but puts people in a situation of increased income risk. It is natural to ask what type of arrangement can be made either to reduce risks or to accommodate risks. Reducing risks could be accomplished by reducing the specialization of workers or having a larger share of economic activity in sectors with predictable demand. Accommodating risks could be accomplished by organizing a system of insurance against the increased risk of loss that specialization brings. If the former results in substantial reductions of output, it could be more efficient for society to choose a 
strategy that encourages international specialization and accommodates the attendant risk through insurance. 1 We know from economic theory that insurance dominates another alternative, namely savings as a protection against loss. In a more general context Milton Friedman (1953) has argued that many arrangements among individuals in a society involve joint advance agreement for redistribution of the product obtained ex post.

The theme which I wish to develop here is that much of the government policy in Germany and other industrialized countries with respect to their labor markets can be regarded as an effort to implement a network of social insurance. Indeed, Soltwedel hints at this in various places in his paper by reference to moral hazard problems. All of the government failures which he identifies can be thought of as the costs of policies designed with an insurance function in mind but with insufficient attention to the resource allocation costs arising from moral hazard problems. In terms of Varian's (1980) model of social insurance, the labor market policies have probably created a larger deadweight cost than they have created social insurance benefits, or at least alternative social insurance arrangements may have had a more favorable benefit-cost ratio.

If we accept the hypothesis of declining rents or quasi-rents of the AICs, there is a fundamental problem for a social-insurance system even if there were no moral hazard problems: as noted by Wilson (1968) if correlated risk leads to insolvency there needs to be a sharing rule (such as proportional) in order to achieve budget balance. Most of the policy schemes set up by government do not have such provisions, and hence a smaller ex post economic pie than anticipated leads to pressures for deficits or other more costly forms of imagining that one can ignore the budget constraint.

\section{B. Kinds of "Insurance" Policies}

What kinds of insurance schemes have been set up for the European AICs, including Germany? In Soltwedel's paper there are basically seven kinds of schemes which I would like to identify in addition to one of my own:

1. Subsidies to firms to continue operation. The cost of these subsidies included the allocation cost of slowed redeployment of industry

\footnotetext{
'We know from economic theory that insurance dominates another alternative, namely, savings as a protection against loss.
} 
and firm resources to new and more attractive lines of business. This prolonged structural unemployment as well as slowed real economic growth, accentuating the problem of solvency indicated above. In Table 9 Soltwede 1 documents the growth of subsidies over the period 1973-1984.

2. Various types of payments to workers. These include mandatory severance payments (see Tables 12 and 13) and increased unemployment insurance (UI) benefits (item 51). I believe that most European countries, including Germany, do not substantially experience a UI payroll tax imposed on employers as is true in the United States, hence, the "insurance" premiums are not adjusted for the number or extent of claims made. In addition there is social-aid payments (Table 15) and progressive income taxes (Tables 16 and 17).

3. Wage leveling. This is accomplished by mandatory minimum wages (Tables 4 and 5). Here the allocation cost of the insurance policy is most obvious if we assume wage departures are a necessary condition to create the quasi-rents needed to motivate migration and retraining in the world of differentiated labor characterizing AICs. Wage "guarantees" which lead to unemployment are scarcely worth writing about as an insurance mechanism. Yet in a policy environment, if a seniority system identifies the layoff order, then these "insider" workers, presumably a majority, are insured.

4. Compulsory collective bargaining. For those knowledgeable about the United States environment where collective bargaining is highly decentralized (except for a few outliers like autos and steel), it should be noted that in Europe collective bargains often cover a wide range of firms and industries. If these broad collective bargains call for moderation to restore an industry's wage level to one compatible with world prices and the exchange rate, this can have favorable effects (unless relative wages within the group need revision). In Soltwedel's account of the matter however, this appears not to have been the case for Germany, and there has been a growth of compulsory collective bargaining agreements (Table 3).

5. Geographic and residential mobility. While not a direct policy measure, this falls into the general category of an institutional influence which provides a form of security or insurance. With restricted mobility plant closing and relocation decisions are more apt to engender political support to preserve the individual's housing location. See, for example, McKenzie (1984).

6. Regulatory restrictions on dismissal. (See Table 11 and Graph 3.) Similar provisions were implemented in Sweden in 1974 and I will return to 
this below. As Soltwedel notes, the cost of this "insurance policy" is an allocation cost which shows up in the form of reduced hires and reduced quits along with the intended benefit of a lower layoff rate. To use the popular term, these appear to be the restricted flows which are characterized as the "Eurosclerosis" of labor markets.

7. Aggregate demand management. Here visible sectors which have erroneously overpriced their products or have failed to adopt new technology, as well as those which are truly in need of insurance, are all temporarily helped by an expansion in aggregate demand. Depending on one's brand of macroeconomics, this may simply create more inflation if there is no economic slack which can create "instant solvency" and restoration of wealth for those experiencing losses.

8. Retraining. This is not discussed by Soltwedel, but I believe that West Germany has a relatively large program in this area. In principle such a program can serve both insurance and allocation functions favorably. The evidence on the effectiveness of such programs is not clear, and Johnson and Tomala (1977) have shown that the intent of the program can be subverted by "fiscal substitution" when it is run by local governments, and it may well be true that when run through the private sector there is fiscal substitution as well.

What can be said of all these eight areas of intervention or institutional restriction on the labor market? To summarize, they can be thought of as driven by insurance motives but can easily run onto the shoals of moral hazard. The argument for compulsory insurance familiar to economists, namely, adverse selection, may simply be overwhelmed by other problems such as solvency and incentives in the implementation of such programs. My point here is to at least offer an explanation of how a set of policies which look bad ex post may not have been brought forth only as the result of rent-seeking or folly. I would argue still further that a complete absence of some form of labor-market insurance would also be costly: workers in a wide range of skills have relatively little wealth not at risk and, absent some form of public or private insurance, may steer away from the sectors of the economy containing such risk.

Countries which have no labor market insurance mechanisms will be revealed by analysts of trade flows as not having a "comparative advantage" in particular industries characterized by labor income risk. These industries, though, are typically the ones which we think of as subject to technological change and as having contributed greatly to the current position of the AICs. 


\section{Additional Evidence on the Above}

Here I would like to offer additional evidence on selected areas indicated above. These are facts about industrial subsidies in other European countries, data on labor-market flows before and after a policy of advance-layoff notification was implemented in Sweden in 1974, data on wage dispersion suggesting less compression in West Germany than indicated by Soltwedel, and a simple comparison of wage flexibility in Germany, Japan, and the United States.

1. Industrial subsidies in Europe. Research by Carlsson (1983) shows that by 19804.0 percent of value added in mining and manufacturing in West Germany could be accounted for by a variety of subsidies such as export subsidies, $R$ and $D$ subsidies, employment subsidies, "rescue" subsidies and specific firm studies. Nor was Germany alone in this by any means. The corresponding figure for Great Britain was 3.6 percent, for Italy it was 7.1 percent, and for Sweden it was 16.0 percent. These subsidies were also quite unevenly distributed so that particular firms and branches of industries were virtually dependent on government "insurance" payments for their survival.

2. Advance layoff notification in Sweden. As shown in Table 1, Sweden had a monthly layoff rate of .30-.36 per hundred workers during the 1971-72 recession. In 1974 a policy of advanced layoff notification was implemented. The intent of the policy was to attenuate the risk of labor-market displacement and adjustment costs. It was designed so that a layoff notice was required for employees who had been with the firm for six consecutive months or a total of 12 months during the last two years, and the duration of lead time varied from one month for employees under 25 years of age to six months if the employee was over $45 .^{2}$

During the next recession after the policy was implemented, 1976-1977, the policy appears to have worked: the layoff rate had declined to less than half of its value in the preceding recession, namely, to .12-.15. The cost of the policy was in the concomitant decline in the quit rate (down to 1.80 and 1.51 from 1.86 and 2.09) and in the even sharper decline in the new hire rate (down to 1.30 and 1.87 from 2.29 and 2.46 ).

3. German wage dispersion reported in other studies. As reported in Be11 and Freeman (1985), wage dispersion increased modestly in West Germany

\footnotetext{
${ }^{2}$ Swedish Laws on Security of Employment, Status of Shop Stewards and Mitigation of Labor Disputes, Ministry of Labor, Stockholm, Sweden, May 1977, pp.11-12.
} 


\section{TABLE 1}

Monthly Layoff, Quit, and New Hire Rate per 100 Workers

Swedish Mining and Manufacturing, 1970-1977

\begin{tabular}{|c|c|c|c|c|c|c|c|c|}
\hline & 1970 & 1971 & 1972 & 1973 & 1974 & 1975 & 1976 & 1977 \\
\hline Layoff & .24 & .36 & .30 & .22 & .16 & .15 & .12 & .15 \\
\hline Quit & 2.92 & 2.09 & 1.86 & 1.94 & 2.20 & 1.95 & 1.80 & 1.51 \\
\hline New Hire & 3.47 & 2.29 & 2.46 & 2.67 & 2.97 & 2.19 & 1.87 & 1.30 \\
\hline \multicolumn{9}{|l|}{ Recession } \\
\hline year $(1-0)$ & 0 & 1 & 1 & 0 & 0 & 0 & 1 & 1 \\
\hline \multicolumn{9}{|l|}{ Persons } \\
\hline \multicolumn{9}{|l|}{ affected $^{a}$} \\
\hline \multicolumn{9}{|l|}{ by advance } \\
\hline layoff notice & - & - & - & - & $1560^{b}$ & 2974 & 4268 & 8350 \\
\hline
\end{tabular}

Source: Layoff, quit and new hire rates are from the Central Statistical Bureau, unpublished data.

aSource: Swedish Employment Policy, 1977-1978, National Labor Market Board, p.53.

b Third and fourth quarters only.

For more information see Studies in Labor Market Behavior:Sweden and the United States, (Gunnar Eliasson, Bertil Holmlund and Frank P. Stafford, eds.) Industrial Institute for Economic and Social Research, Stockholm, 1981. 
between 1975 and 1982 and went up in the United Kingdom as well. France, Spain, Italy, and Switzerland either experienced a reduction or no change in wage dispersion. Japan experienced an increase in wage dispersion, starting from a level above all the other countries in the comparison, and the United States was most strongly characterized by growing interindustry wage dispersion. In this context it could be argued that given the adjustments which should have taken place in West Germany, a still larger dispersion would have been helpful. However, I believe that Soltwedel's examination of legislated or bargained minima may lead to an erroneous impression of what is happening to transaction wages.

A doctoral student of mine at Michigan, Filip Abraham, has found that in Belgium manufacturing wage dispersion fell from 1965 to 1975 and rose moderately thereafter. His analysis shows a modest but steady rise in manufacturing wage dispersion over the period 1965-1980 for West Germany. Sweden, while having the lowest wage dispersion of any AIC, has still managed to attain reasonably strong economic growth.

4. Compensation changes in Germany and other countries. Annual compensation changes in manufacturing for West Germany compared to those for Japan and the United States for the period 1970-1984 are presented in Table 2. The pattern shown in Table 2 is one in which both West Germany and Japan were experiencing rapid real compensation increases until the first oil shock. Subsequently, from 1975 on, Japan's annual percentage increases have been lower and more variable, whereas those for Germany are persistently strong until the 1980s, and from then on are more moderate and variable. The United States compensation increases are more humble even during the 1970s, and are moderate and quite variable throughout the entire period.

It could be argued that since 1981 West Germany has moved toward a more flexible compensation growth pattern as some of the insurance functions have given way to interest in long-term growth. That is, some of the concerns expressed in Soltwedel's paper have been acted upon, and allocation issues have a larger play in labor-market policy and institutions. With moderation in compensation, one would expect a smaller excess supply of labor. On the other hand many of the side effects of insurance policies remain. The net return to market search, mobility, and employment are reduced. This is because of income payments, wage leveling, and other impediments indicated in this discussion. 
Percent Annual Change in Real Hourly Manufacturing Compensation West Germany, Japan, and the United States, 1970-1984

\begin{tabular}{|c|c|c|c|}
\hline \multirow[t]{2}{*}{ Year Ending } & \multicolumn{3}{|c|}{ Country } \\
\hline & West Germany & Japan & United States \\
\hline 1970 & 14.2 & 10.5 & 1.0 \\
\hline 1971 & 6.7 & 8.7 & 1.6 \\
\hline 1972 & 4.5 & 9.5 & 2.0 \\
\hline 1973 & 6.0 & 9.7 & 1.2 \\
\hline 1974 & 6.5 & 5.3 & -0.4 \\
\hline 1975 & 3.8 & 4.2 & 2.3 \\
\hline 1976 & 3.7 & -1.5 & 2.3 \\
\hline 1977 & 5.7 & 2.1 & 2.0 \\
\hline 1978 & 4.7 & 2.5 & -3.1 \\
\hline 1979 & 3.2 & 2.8 & 2.2 \\
\hline 1980 & 3.1 & -1.5 & -1.8 \\
\hline 1981 & 0.6 & 2.4 & -0.5 \\
\hline 1982 & -0.5 & 2.3 & 2.3 \\
\hline 1983 & 1.8 & 1.4 & -0.2 \\
\hline 1984 & 2.4 & 1.0 & -0.6 \\
\hline 1985 & - & -0.4 & 1.3 \\
\hline
\end{tabular}

Source: Economic Report of the President, United States Government Printing Office, Washington, D.C., 1987. Tables B-105, B-106, B-107. The compensation index was deflated by the CPI and for West Germany and Japan was converted back into domestic currency value. 


\section{REFERENCES}

Be11, L.A. and Freeman, R.B.

(1985) Does a Flexible Industry Wage Structure Increase Employment?:

The U.S. Experience. National Bureau of Economic Research, Working Paper No. 1604

Carlsson, B.

(1983) Industrial Subsidies in Sweden: Macroeconomic Effects and an International Comparison. Journal of Industrial Economics, (32): 1-23.

Friedman, $M$.

(1953) Choice, Chance and the Personal Distribution of Income. Journal of Political Economy, 61: 277-290.

Johnson, G. and Tomola, J.

(1977) The Fiscal Substitution Effect of Alternative Approaches to Public Service Employment. Journal of Human Resources, (12): 3-27.

McKenzie, R.B.

(1984) Fugitive Industry. San Francisco: Pacific Institute for Public Policy Research.

Varian, H.R.

(1980) Redistributive Taxation as Social Insurance. Journal of Public Economic, 14: 49-68.

Wilson, $R$.

(1968) The Theory of Syndicates. Econometrica, 36: 119-132. 